DOI: 10.2478/linpo-2013-0019

\title{
EVOLUTION OF STATIVE PARTICIPLES IN PAHARI
}

\author{
KRZYSZTOF STROŃSKI
}

\begin{abstract}
Krzysztof Stroński. Evolution of Stative Participles in Pahari. Lingua Posnaniensis, vol. LV (2)/2013. The Poznań Society for the Advancement of the Arts and Sciences. PL ISSN 0079-4740, ISBN 978-83-7654-274-4, pp. 135-150.
\end{abstract}

The point of departure for the present paper is the status of the bare participial form as inherited from MIA (Middle Indo-Aryan) by early NIA (New Indo-Aryan) with its stative force.

It is a very well known phenomenon in the contemporary IA languages that the past participle can be extended by a past participle form based of the verb to be (e.g. MSH - Modern Standard Hindi - hua a). It is also noticeable that not all NIA languages allow such extension and that several languages developed further, and reinterpreted the extended forms. The aim of the present paper will be to demonstrate how the stative participles developed in two branches of IA, namely Eastern and Western Pahari. ${ }^{1}$

The data for this preliminary research has been excerpted from Western Pahari inscriptions (CHHABRA 1957), Eastern Pahari inscriptions (POKHAREL 1974; CAUHĀN 2008; Joshi 2009), reference grammars and folk texts.

KeY wORDS: stative participles, Pahari, tense-aspect paradigm, grammaticalization

Krzysztof Stroński, Chair of Oriental Studies, Adam Mickiewicz University in Poznań, stroniu@amu.edu.pl

\section{INTRODUCTION}

The view that the P-oriented construction in OIA (Old Indo-Aryan) based on the -ta participle was of active-resultative character, and has preserved its active status developing into past tense/perfective in NIA, has received considerable attention in the literature (cf. Peterson 1998).

The employment of the -ta participle with agent marked by oblique case can be traced in NIA from its earliest records, along with the agentless constructions. Recent research has also contributed to the view that the construction based on the -ta participle has always admitted a resultative perfect interpretation (Deo 2006). In Vedic, it was a stative realizing resultative aspect, in epic Sanskrit, a form referring to past events, and from MIA onwards, a form licensing perfective aspect.

In many NIA languages the past participle can be extended by the past participle based on the verb 'to be' reinforcing its stative force (cf. LiENHARD 1961: 184). Pahari languages

1 The notion of Eastern and Western Pahari has been here applied in the same vein as In JosHI \& NeGI (1993) who have reinterpreted the classification proposed by Grierson, grouping Kumauni, Garhwali and Nepali under Eastern Pahari branch and all the others under Western Pahari. 
represent several interesting developments in this regard. In Western Pahari the participle has presumably lost its stative character, and a new participial form extended with an auxiliary be has appeared (cf. HENDRIKSEN 1986). Now the stative participle is being reinterpreted as a basis for perfective tenses (cf. ȚHĀKUR 1975).

In Eastern Pahari either the auxiliaries ('remain' and 'put'), which reinforce the stative value of the participle have been employed (SHARMA 1987), or the participial form has been extended with pleonastic suffixes etymologically identified with possessive markers (cf. SHARMA 1987; WALLACE 1982). In the present paper I will try to focus on these developments.

\section{STATIVE FORCE OF THE -ta PARTICIPLE IN NIA}

Some contemporary NIA languages seem to preserve the stative force of the past participle. Examples (1) contrasted with (2) and (3) show that the bare participle can still convey stative meaning.

$$
\begin{array}{ll}
\text { vah baitha } & \text { hai } \\
\text { he sit.PPP.M.SG } & \text { be.AUX.PRES.3SG } \\
\text { 'He is seated.' } &
\end{array}
$$

$\begin{array}{llll}\text { vah } \quad \text { baithā } & \text { hua } & \text { hai } \\ \text { he } & \text { sit.PPP.M.SG } & \text { be. PPP.M.SG } & \text { AUX.PRES.3SG } \\ \text { 'He is seated. } & & \end{array}$

'He is seated.'

$\begin{array}{llll}\text { vah } & \text { baith } & \text { gaya } & \text { hai } \\ \text { he } & \text { sit } & \text { go.AUX.PPP.SG } & \text { be.AUX.PRES.3SG }\end{array}$

'He has sat down.'

(cf. van OLPHEN 1978: 188-189)

There are syntactic and semantic restrictions on the usage of stative participles in resultative constructions depending on the verb diathesis. ${ }^{2}$ For example, S-oriented resultative constructions in Hindi/Urdu show no particular constraints whereas O-oriented and A-oriented ones do. O-oriented resultatives are formed from verbs which denote establishing spatial relations between two items (e.g. rakhnā 'put'), causing existence (e.g. banānā 'make', likhna 'write') etc. A-oriented resultatives seem to have more rigid constraints here prevalent verbs are those related to garments or ornaments wearing, body movements,

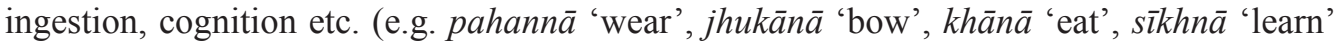
etc.). Some A-oriented resultatives have already become idiomatic expressions e.g. parh $\bar{a}$ huā 'learned' i.e. 'educated' (cf. DAščENKo 1987: 118-186).

It has also been mentioned in the literature that there are several constraints on stative participles in Hindi-Urdu as regards the usage of the extended vs. simple form. For example, MSH prefers non-extended forms from intransitives such as baithnn ' 'sit', lețna 'lay', parnna

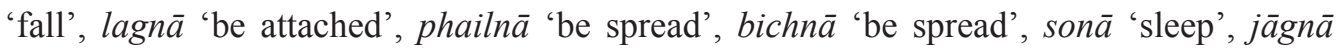
'wake up', cipaknā 'adhere', occur usually with verbs such as pahanna 'to wear', pakarnā 'catch', len $\bar{a}$ 'take', sãbhāln $\bar{a}$ 'take care of' (cf. LIPEROVSKIJ 1976: 103, 110).

2 Depending on whether the underlying subject of a state refers to $\mathrm{S}$ (subject of an intransitive clause), $\mathrm{O}$ (object of a transitive clause) or A (subject of a transitive clause) I will distinguish S-, O- and A-oriented resultatives/statives (cf. NeDJALKov \& JAXONTOV 1988; KHOKHLOVA \& Singh 2007). 
A-oriented resultatives in MSH do not allow A marking (which is in standard grammars reserved only for perfective tenses), however, colloquial Hindi, under the influence of Punjabi, has introduced a construction which weakens the constraint imposed in MSH and A-oriented extended past participle occurs with ergatively marked A (4). ${ }^{3}$

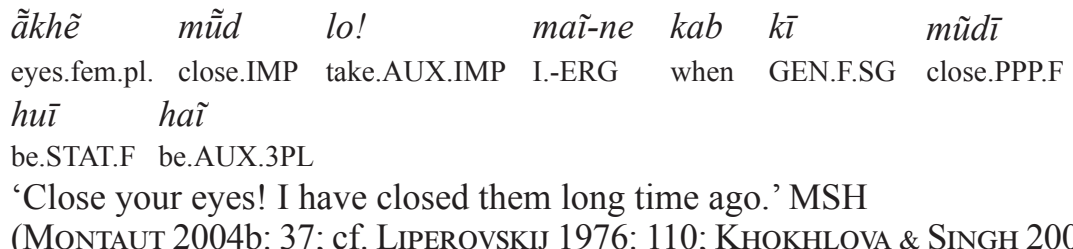

\section{STATIVE PARTICIPLES IN PAHARI}

In Nepali the past participle terminating in $-y a$ has been extended by - $k o$ (presumably a GEN marker) in order to build new perfective. This process took place around the

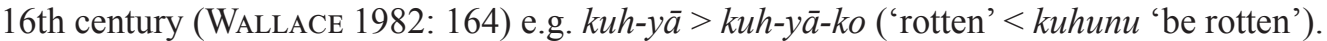

The extended form appeared then in both attributive (5) and predicative (6) functions (WALlace 1982: 194). Such an extended form constituted the basis for the perfect tenses (cf. Grierson 1916: 38-39; Wallace 1982: 193).

$$
\begin{aligned}
& \text { kuh-yāko māsu } \\
& \text { rot-PPP.M.SG. meat } \\
& \text { 'rotten meat.' }
\end{aligned}
$$

$$
\begin{array}{llll}
\text { savai maimtraheru-kana mai-le jap-yāka } & \text { chan } \\
\text { all incantation.PL-ACC I-ERG } & \text { repeat-PPP.M.PL } & \text { be.PRES.3PL } \\
\text { 'I have repeated all incantations.' } &
\end{array}
$$

Kumauni, a language closely related to Nepali, has not extended the bare participial form with the -ko suffix until recently. GRIERSON in his LSI (1916: 135) gave examples of three possible forms of the PPP: two verbal and one adjectival. Verbal PPP could be weak or strong, the former being used with perfective tenses and the latter with the simple past. So-called weak form had only two possible terminations $-a$ (M.SG/PL) and $-i$. (F.SG/PL) > hitacch 'he has/they have gone', hiți-chh 'she has/they (F.) have gone' whereas strong forms had gender-number terminations for the 3rd person (-o M.SG, $-a$ M.PL, $-i$ F.SG/PL > hițo 'he went', hițà 'they went', hiți 'she went/they (F.) went') and additional person terminations for the 1 st and 2 nd pers. of S and the unmarked $\mathrm{O}$ (e.g. hit $\tilde{u}$ 'I went'). ${ }^{4}$ Adjectival form had termination -iyo, e.g. lekhiyo tàmà patr 'written copper tablet' (GRIERSON 1916: 136).

Grierson's samples of Kumauni show no instances of the -ko or more recent $-y \bar{a} k o$ forms, however modern grammars already mention them e.g. mari-yāko < marno 'die' (cf. SHARMA

3 This form has been attested at least from the beginning of the 20th century (cf. PнiLlot 1926).

${ }^{4}$ Although there are no forms of the past tense with the unmarked $O$ other than 3rd person of the type (a) such constructions are present in contemporary Kumauni dialects (cf. SHARMA 1994: 206-207; STROŃSKI 2011: 93).
(a)

$$
\begin{array}{lll}
\text { wi-le } & \text { maĩ } & \text { mārũ } \\
\text { he-ERG } & \mathrm{I} & \text { kill.PPP.1SG }
\end{array}
$$$$
\text { 'He killed me.' }
$$ 
1987: 124). The extension appears to be limited geographically (for particular examples see SHARMA 1994: 274-275).

Later on, Kumauni has abandoned both verbal forms of the PPP, and now only an adjectival form is employed in the simple past whereas perfective tenses use the converb (conjunctive participle) in $-i$. The old form in -iyo has undergone a number of phonetic changes - especially stems terminating in a vowel (e.g. sikhäiyo $>$ sikhāyo $>$ sikhā; gāiyo $>$ gau $>$ go; diyo $>$ de etc.). Stems terminating in consonants can still preserve -iy-element e.g. dekhiya 'seen.PPP.M.PL'.

With advancing gender attrition, PPP in western dialects of Kumauni has entirely lost vowel endings and it has acquired a uniform termination - $\bar{l}$, e.g. Eastern Kumauni mario/ mariyo ädim and marī saini 'dead woman' vs. Western Kumauni marī ādim/sen̄̄ 'dead man/ woman' (SHARMA 1987: 124). Similarily Garhwali has a uniform PPP form terminating in - $e$ with no gender/number distinction.

Both Kumauni and Garhwali seem to employ converbs in $-i$ with several auxiliaries such as rākhan, hālaṇ 'put' (for transitives), rūn 'remain', jān 'go' (for intransitives) in order to convey stative or resultative meanings (cf. Kumauni examples (7) and (8)) but the bare PPP has still preserved its stative force as can best be seen in constructions with verbs 'put on', 'wear' etc. (see (9)), (cf. KHokHLOva \& Singh 2007: 96). As we will see in the next section, the employment of some auxiliaries in Pahari shows close affinities to other NIA tongues.

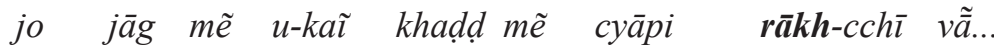
which place LOC he-ACC hole LOC press.CNV put-is.PAST there 'In the place in which he had been buried in the hole, there ...'

(PANT 2006: 36)

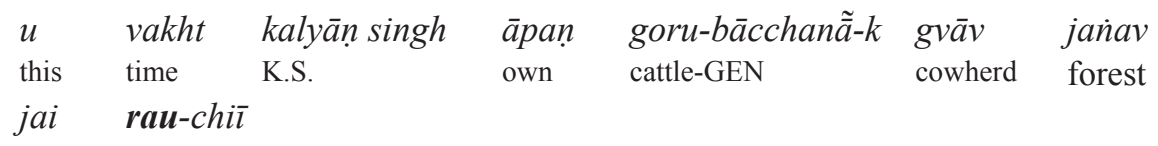

go.CNV remain-be.AUX.PAST

'That time Kalyān Singh was gone to the forest to graze his cattle (lit. was gone to the forest to the cowherd community of his own cattle).' (PANT 2006: 36)

$\begin{array}{llll}\begin{array}{l}b u d h y \bar{a}-k \bar{l} \\ \text { old man-GEN }\end{array} & \begin{array}{l}\text { duphāryā } \\ \text { torn }\end{array} & \text { topi } & \text { pairĩ } \\ \text { cap.F.SG } & \text { wear.PPP.F.SG }\end{array}$

'The old man was wearing a torn cap.' (Garhwali) (BıșṬ \& Jośī 2005: 126)

What we see in Kumauni in the last 100-150 years is the disappearance of the verbal PPP forms in the system of past tenses and perfective tenses. The past tense has been entirely ousted by the former adjectival participle and the perfective tenses are formed on the basis of the converb. The contemporary situation is thus straightforward - one form of the PPP serves as an attribute and a verbal simple past form, with an extended form -yako appearing rather occasionally.

Early Western Pahari shows almost no attestations of the synthetic stative participles. In the collection of inscriptions collated by CHHABRA (1957) I have found only one example of the past participle which formally and semantically can be classified as a stative participle:

$$
\begin{array}{lllll}
\text { simā saingha } & \text { je } & \text { pice } & \text { śrīganeśs rì } & \text { patee } \\
\text { boundary line } & \text { which } & \text { behind } & \text { ilustrous G. } & \text { title deed }
\end{array}
$$

likh-or-ī

write-STAT-F.SG 


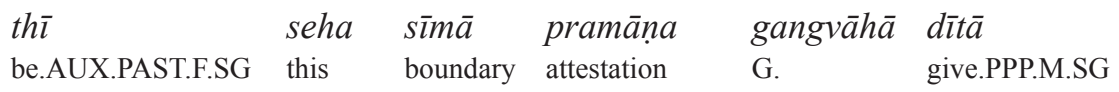

'The Gangavaha has been given away with the same boundary line which had been written down in the title deed of the ilustrous Ganesha.'

A.D. 1595 (CHHABRA 1947: 93)

On such a modest evidence one cannot judge to what extent stative participles in early Western Pahari were incorporated into verbal system.

Some western dialects attach the following auxiliaries to the PPP of the main verb: e.g. Kotgarhi nds, no; Koci ndo, do (< PrP of the verb 'be' hundo; cf. BAILEY 1908: 15, 28; HENDRIKSEN 1986: 177).

$$
\begin{aligned}
& s \bar{\partial} \quad b \bar{e} f: \supset \quad \text { no } \\
& \text { he sit.PPP.M.SG STAT.M.SG } \\
& \text { 'He is sitting.' Kotgarhi }
\end{aligned}
$$

(HENDRIKSEN 1986: 178)

Other contemporary Western Pahari dialects such as Chameali, Mandeali, Koci Kuari, Jubbali or Bhadrawahi show stative participles which seem to be continuation of the form attested in (10), e.g. they use a combination of a short converb (in $-i$ or equal to the root) and the PPP form of the auxiliary erno, orṇo 'do, see' (e.g. Chameali hir-or- $\bar{a}$ 'lost-STAT.M.SG' (GrIERSON 1916: 836), Koci Kuari khai + ero 'eat.CNV + PPP.AUX.M.SG. > having been eaten' (HENDRIKSEN 1986: 178)).

Interestingly, up to the 19th century Kului did not employ any suffixes building statives (cf. BAILEY 1908; GRIERSON 1916). Grierson's examples show that still in the 19th century full auxiliaries were employed e.g. mord $\bar{a}-l \bar{a} g \bar{a}-h u n d \bar{a}-s \bar{a}$ 'I am in the state of dying' whereas contemporary Kului shows two suffixes $-u(n) d \bar{a}(<$ hundā) and -irā (presumably the extension of the PPP is a grammaticalized genitive postposition $r \bar{a} / r \bar{\imath}$ e.g. likhia $+r \bar{\imath}>$ likhir $\bar{l}$ (pustak) 'written (book)' (cf. ȚHĀKUR 1975: 296-297)) as markers of perfectivity (see (12)) and (13)). Kului went further, in fully incorporating stative participles into its perfective system. As mentioned by ȚHĀKUR (1975: 305-306), bare participial forms have been almost ousted by stative participles in the spoken language, the only exception being simple past tense (cf. (12) and (13) with (14)).

$$
\begin{array}{lllll}
\text { tei-ai } & s \bar{a} r \bar{a} & \text { sãs } \bar{a} r \bar{a}-b e & \text { banā-uda } & s \bar{a} \\
\text { he.OBL-ERG } & \text { whole } & \text { world-ACC } & \text { make-STAT.M.SG } & \text { be.PRES.SG } \\
\text { 'He has created the whole world.' } &
\end{array}
$$

(Kului) (G.R.)

$\begin{array}{llll}d \bar{a} d \bar{l}-a i & \operatorname{rot} \bar{l} & p a k \bar{a}-i r \bar{l} & t h \bar{\imath} \\ \text { grandmother-ERG } & \text { bread.F.SG } & \text { cook-STAT.F.SG } & \text { be.AUX.PAST.F.SG }\end{array}$

'The paternal grandmother had cooked bread.' (Kului) (ṬHĀKUR 1975: 240)

$$
\begin{array}{lll}
d \bar{a} d \bar{l}-a i & \operatorname{rot} \bar{\imath} & \operatorname{pak} \bar{a}-\bar{l} \\
\text { grandmother-ERG } & \text { bread.F.SG } & \text { cook-PPP.F.SG } \\
\text { 'The paternal grandmother cooked bread.' }
\end{array}
$$

(Kului) (ṬHĀKUR 1975: 240)

Presumably, a similar development must have taken place already in the 19th century in Padari - the dialect of the Bhadrawahi group. Here also the stative participle has been employed to build perfective tenses (see (15)) as it is the case in contemporary Kului (GRIERSON 1916: 910). The bare past participle was used exclusively for the simple past tense. 


$\begin{array}{lllll}\text { tiūn- } b \bar{a} b b-\bar{e} & \text { matā } & \text { dhām } & \text { kěōr } & h^{i} \\ \text { you.GEN-father-ERG } & \text { great } & \text { feast.FEM.SG } & \text { do.STAT } & \text { be.FEM.SG } \\ \text { 'Your father has made a great feast.' } & & \text { (GRIERSON }\end{array}$

(GRIERSON 1916: 910, 912)

As an interim summary we can assume that, regarding the possible development of the PPP in Eastern Pahari, there are at least two scenarios: either PPP has lost its stative force and has been extended by a suffix -ko (e.g. Nepali) or it preserved its stative character (e.g. Kumauni and Garhwali (cf. (9)). ${ }^{5}$

Another possible scenario is realization of the stative/resulative meaning by employment of a converb and an auxiliary (Kumauni, Garhwali).

In Western Pahari one can observe a variety of auxiliaries which have been employed to build new stative participles. In certain dialects auxiliaries do or see have been employed to build stative participles (Koci Kuari, Jubbali, Mandeali) in others these auxiliaries (or already gramaticalized, shortened forms) started being employed as perfective markers (Kotgarhi, Koci) and, lastly, stative participles could be fully incorporated into perfective system (e.g. Kului, Padari).

\section{COMPARATIVE EVIDENCE}

Comparative evidence shows that early NIA languages could employ a present participle of an auxiliary to be to form an extended participle. This is certainly the case in Old Marwari where we do not find any examples of the synthetic type attested in Western Pahari inscriptions. Examples given by TeSsitori (1915: 104) show only an attributive character of the extended form, e.g. giu hütaü 'go.PPP.M.SG be.AUX.PART.PRES.M. $\mathrm{SG}>$ i.e. 'gone', but I have come across constructions in which the predicative interpretation cannot be excluded. Of course, it is not always possible to distinguish the attributive function from the predicative one but it seems that the position of the participial form can be regarded as a decisive factor - cf. example (16) with a post-NP position and (17) with a pre-NP position.

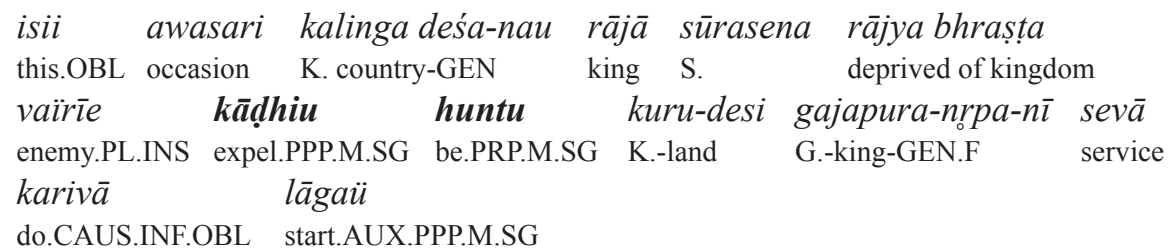

'That time, Shürsena, the king of the country of Kalinga, deprived of his kingdom was expelled by his enemies and he began his services in the land of Kuru under the king of Hastināpura.'

(R.G. 31; A.D. 1515)

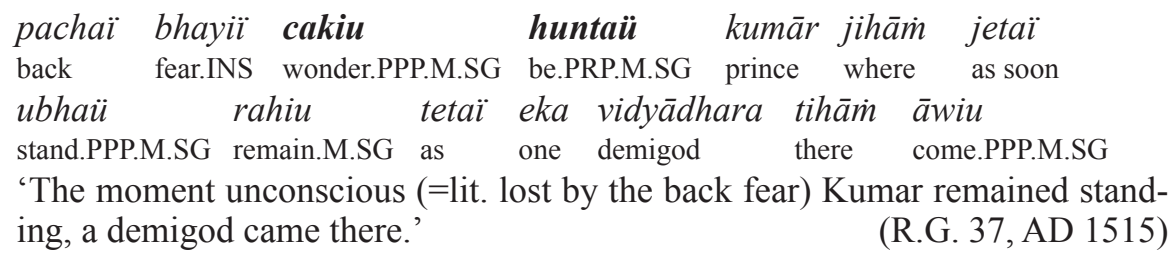

5 Although it seems that in Kumauni the optional extension of the PPP by an -eko suffix can be perceived as a sign of the changing status of the PPP. 
The possibility of a predicative interpretation is further strengthened by the absolutive usage of extended participial forms such as below:

$\begin{array}{llllll}\text { sanghi jāwä̈ } & \text { tihām } & \text { gay } \bar{a} & \text { hüntāim } & \text { tumha-rahaïm } \\ \text { community go.IMP.2SG } & \text { there } & \text { go.PPP.M.PL be.PRP.M.PL } & \text { you.OBL-DAT } \\ \text { sangha-rakșa } & \text { punyu } & \text { yaśu yaśu be bola } & \text { hosiüm } \\ \text { protection of the comunity } & \text { welfare fame fame two word.F } & \text { be.FUT.3SG }\end{array}$

'Go to the community; having gone there you will obtain two things: the protection of the community and fame.'

(R.G. 11; AD 1411)

Rajasthani prose texts from the 17 th century show already that the extended form ceased to be used. In the attributive and predicative functions only bare PPP was employed (cf. (19)). Old constructions extended by the present participle of 'to be' have been reinterpreted as past perfect (via reinterpretation of the present participle as an imperfect form humtaü> hutaü> hataü cf. MSH hotā) (cf. TESSITORI 1915: 75, 96).

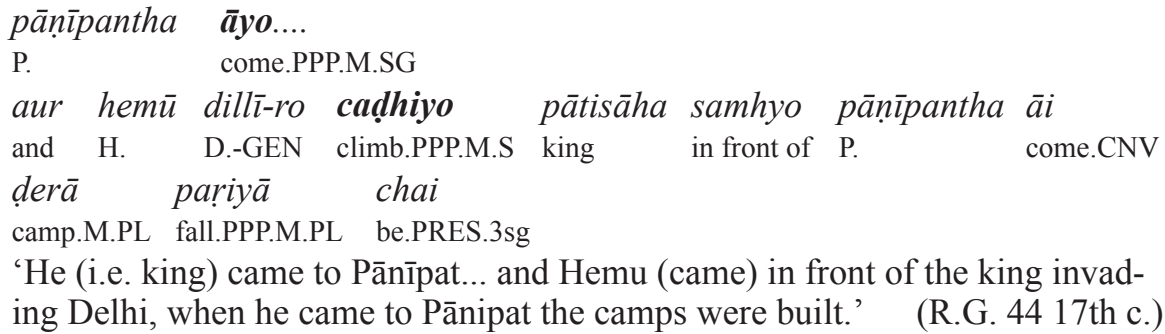

By the 18th century Marwari introduced an extended form consisting of the PPP of the main verb, the PPP of an auxiliary to be and a present or past form of the auxiliary to be e.g.:

$$
\begin{array}{lllll}
\text { itne } & p \bar{i} r & \text { bhele } & \text { hue } & \text { hai } \\
\text { so many.M.PL } & \text { saint.M.PL } & \text { gather.PPP.M.PL } & \text { be.PPP.M.PL } & \text { be.AUX.PRES.3SG }
\end{array}
$$

'So many saints are gathered.'

(KHOKHLOVA 1999: 94)

It has also been noted that in early Marwari as well as in Awadhi another possible form of the PPP was used, namely extended by the PPP of the verb rahana 'remain', e.g. Marwari anaboliu rahiu '(he) remained silent', Awadhi gaye rahe 'they had gone'. However in the former language the form has been labelled 'continuative' ${ }^{6}$ whereas in the latter 'contingent or past perfect' (Tessitori 1915: 104; KellogG 1893: 322-323). As we have seen in the previous section contemporary Eastern Pahari tends also to use the auxiliary 'remain' to convey resultative meaning. Hindi/Urdu also allows the PPP from rahnā 'remain' along with hon $\bar{a}$ 'be' to build resultatives (for an exhaustive discussion see DAŠČENKO 1987).

Forms such as māriyo-ro and māriyo-huwo 'dead' were reported to be used adjectively by the end of the 19th century (GRIERSON in his LSI (1908: 26). Contemporary Marwari has extended the function of the PPP forms in -ro (presumably a genitive marker) to denote resultative (cf. KHOKHLOva \& Singh 2007) or presumptive meanings (see (21) and (22)). Other dialects of the Western Rajasthani branch such as Shekhawati, Bagri, Mewati also use the extended forms. It seems that at least Western Rajasthani allows further extension of the stative form by the PPP of the verb to be in its attributive function, e.g. mariy-or-o hoyo

6 Continuative interpretation is also possible for the MSH extended PPP form followed by the auxiliary 'to be' in the past tense e.g. basī huī thī 'she stayed' (LiENHARD 1961: 191). 
'dead' (GuSAIN 2000: 57; 2001: 46; 2003: 47). On the other hand dialects belonging to the Eastern Rajasthani branch do not employ extended forms at all (ŚARMĀ 1991: 75, 188-189).

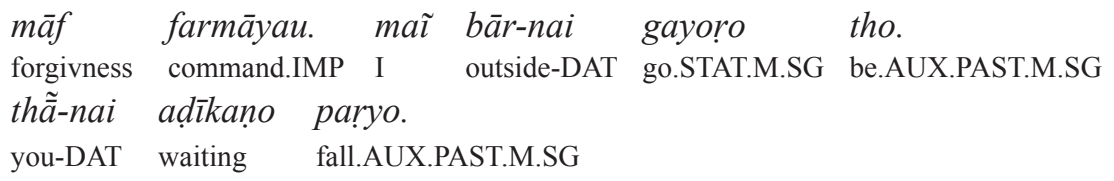

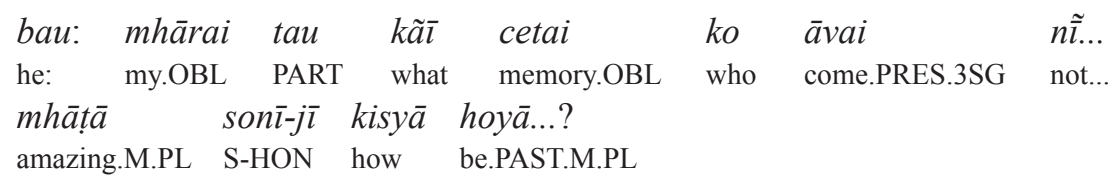

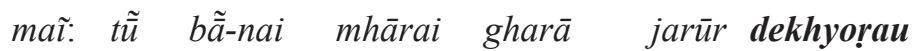

I: you he-ACC my.OBL house.OBL surely see.STAT.M.SG

hai. tī bhūl gyao hai.

be.AUX.PRES.3SG you forget go.AUX.PAST.M.SG be.AUX.PRES.3SG

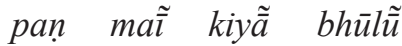

but I why forget.SUBJ.1SG

He: 'I don't remember anybody like that. How is this amazing Soni?

I: You must have seen him in my house. You have forgotten. But why should I forget?'

(Mānak 2008 January: 18)

According to Nedjalkov \& JAXONTOV (1988: 46) Hindi belongs to the group of languages having specialized forms for passives and resultatives. The markers for both categories should thus be in complementary distribution and indeed one cannot find forms of the type (23) combining passive and resultative markers whereas in contemporary Marwari this is not unusual. In the form gūnth-ïj-yori appearing in the example (24) both passive and resultative suffixes are present. There is however typological evidence for such coexistence in other Indo-European and non-Indo-European languages e.g. Armenian or Japanese (cf. Nedjalkov \& JaXontov 1988: 46; KhoKhlova 1999: 97).

Due to attrition of the A marking Marwari A-oriented constructions based on the stative participle are fully nominative (cf. KHOKHLOVA 1999: 109; KHOKHLOVA \& SINGH 2007: 97).
$(23)^{*}$
$k h \bar{a} y \bar{a}$
gaya
$h u \bar{a}$
hai
eat.PPP.M.SG
go.AUX.PPP.M.SG. be.STAT.M.SG
be.AUX.PRES3SG
*'is been eaten'

\begin{tabular}{|c|c|c|c|c|c|c|}
\hline $\begin{array}{l}\text { kittai } \\
\text { how much }\end{array}$ & $\begin{array}{l}\text { pyār } \\
\text { love }\end{array}$ & $\begin{array}{l}s \tilde{\bar{u}} \\
\mathrm{ABL}\end{array}$ & $\begin{array}{ll}m o j \bar{a} & a r \\
\text { sock.M.PL } & \text { and }\end{array}$ & $\begin{array}{l}\text { svețar } \\
\text { Sweter }\end{array}$ & $\begin{array}{l}\text { bunyea } \\
\text { weave.PPP.M. }\end{array}$ & \\
\hline$h \bar{a}$ & & har & phãdai & $m \tilde{e}$ & $u n-r \bar{l}$ & mamtā \\
\hline $\begin{array}{l}\text { e.AUX.P } \\
\bar{l}\end{array}$ & T.M & $\begin{array}{l}\text { each } \\
\text { an } \tilde{\bar{a}}\end{array}$ & $\begin{array}{l}\text { stich.M.SG.OBL } \\
\text { gũuth-īj-yor- } \bar{l}\end{array}$ & LOC & $\begin{array}{l}\text { she.OBL-GEN.F } \\
\bar{l}\end{array}$ & love \\
\hline
\end{tabular}

'With how much love (she) had woven socks and sweaters, in each stitch the throbbing of her love had been knitted.'

(Māṇak 2008 January: 28)

There is evidence from other IA languages which use two PPP forms. Punjabi has an extended form which has been attested at least since the 18th century (see (25); KHOKHLOVA 
1999). Contemporary Punjabi differentiates between non-extended and extended forms, the former marking perfective whereas the latter resultative constructions (26a and 26b). The resultative character of the extended form was noted already in the 19th century (cf. NewTON 1898: 297-298). Punjabi A-oriented resultatives have A marked by an ergative case (cf. KhoKhlova \& Singh 2007).

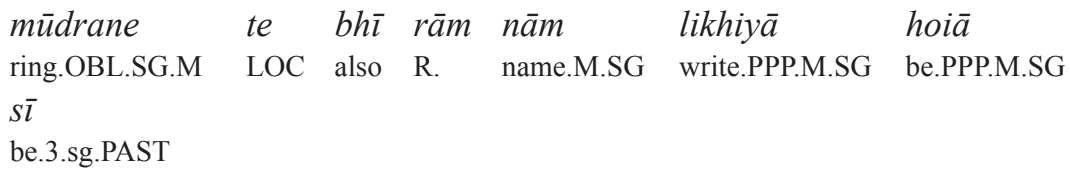

'Ram's name was also written on the ring.' Old Punjabi 17th-18th centuries

(KHOKHLOVA 1999: 94)

(26a) uhne paise cupāke rakkhe hoe han he.ERG money.M.PL hide.CNV keep.PPP.M.PL be.STAT.M.PL be.AUX.PRES.3SG 'He has his money hidden.'

(26b) uhne paise cupāke rakkhe han he.ERG money.M.PL hide.CNV keep.PPP.M.PL be.AUX.PRES.3SG 'He has hidden the money.' ～(cf. Khokhlova \& SingH 2007: 97)

Gujarati has two forms of the PPP - one simple in $-y$ - which builds all perfective tenses and another one having two variants: not inflected in -el and inflected in -el- (cf. SAVELEVA 1965: 42-46).

From TiSDALl (1892: 56) and Bhatт (1889) it is clear that forms in -el-/-el conveyed stative meanings already in the 19th century, however in Grierson's treatise on Old Gujarati Grammar from the end of the 14th century (GRIERSON 1908: 360-362) and from the 16 th century in DAVE (1935) there are no traces of extended forms. What is more, in RAMSAY (1842), extended forms are not mentioned either.

On one hand contemporary works on Gujarati distinguish constructions based on the extended form in $-e l-(-e l)$ from the short forms in $-y$, labelling the former resultative or completive and the latter perfective (see ex. (27) and (28); cf. Doctor 2004: 49; Khokhlova 1999: 110; Khokhlova \& Singh 2007: 93). On the other hand the two forms are also treated synonymously (cf. Saveleva 1965: 42-46; Cardona \& Suthar 2007: 687). Extended forms are syntactically equal to the simple forms, i.e. transitive verbs preserve A marking.

Interestingly, Gujarati can also combine passive and resultative markers similarily to Marwari e.g. dekh-a-a-yel-o 'see-PASS-STAT-M.SG 'in state of being seen' (cf. KHOKHLOVA 1999: 97).

$$
\begin{array}{lllll}
m \tilde{e} & \text { rastā } & \text { par } & \text { sāp } & \text { jo-yel-o/jo-yel } \\
\text { I.ERG } & \text { road.M.SG.OBL LOC } & \text { serpent.M.SG } & \text { see-STAT-M.SG./see-STAT } \\
\text { 'I saw a serpent on the road.' } & &
\end{array}
$$

(http://ccat.sas.upenn.edu/plc/gujarati/pluperfect.htm)

$$
\begin{aligned}
& \text { sudhā-e radio } \quad \text { kharid-y-o / kharid-el-o } \\
& \text { Sudha-ERG radio.M.SG buy-PPP-M.SG / buy-STAT-M.SG } \\
& \text { 'Sudha bought/had bought a radio.' }
\end{aligned}
$$


The inclusion of the extended forms into the tense-aspect system has also been noticed for Marathi, where extended forms in -lel- started being employed only recently (KATENINA 1963: 197; PANDHARIPANDE 2007: 708). Older grammars of Marathi did not register such forms at all (e.g. BLOCH 1920). In the second half of the 20th century forms in -lel-started being employed both attributively (29) and predicatively (30), the latter form being an innovation. As remarked by Katenina (1963: 197) the participles in -lel-, when used predicatively, emphasize the meaning of the completion of an action or process up to the present moment and this particularity differentiaties them from the perfect forms based on the - $l$ - participle (31).

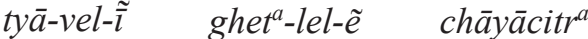

$$
\begin{aligned}
& \text { this-time-LOC take-STAT-N.SG photo.N.SG } \\
& \text { 'The photo taken this moment.' }
\end{aligned}
$$

(KATENINA 1963: 196)

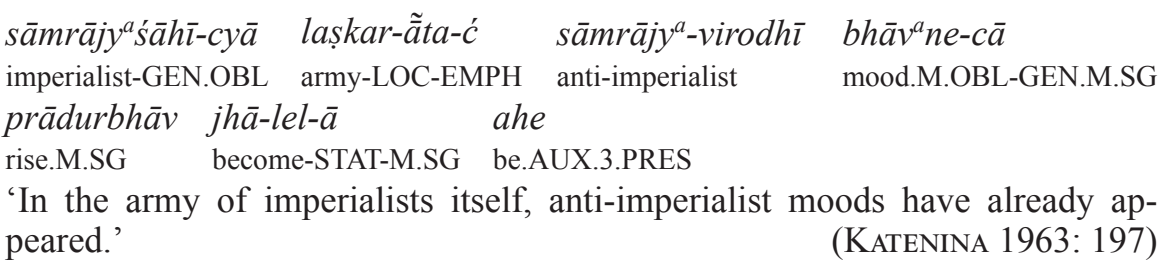

$\begin{array}{llll}\text { gìt } \bar{a} & \text { śăle-t } & \text { ge-l- } \bar{l} & \bar{a} h e \\ \text { G. } & \text { school.LOC } & \text { go-PPP-F.SG } & \text { be.AUX.3SG.PRES }\end{array}$

'Gita has gone to school.'

(PANDhaRiPANDE 2007: 707)

What is more, in contemporary Marathi incorporation of the extended form in -lelwent further, cliticizing the copula. Such forms have been attested in Marathi internet blogs (P. E. Hook p.c.).

$\begin{array}{lllllll}t \bar{u}-c & n a h \bar{\imath} & k \bar{a} & \text { sakēl-i } & \text { fon } & \text { ke-lel-ās } & \text { ma-lāe } \\ \text { you-EMPH not } & \text { what morning-LOC phone } & \text { do-STAT-2SG } & \text { I-DAT } \\ \text { 'Haven't you called me in the morning?' } & \end{array}$

Sindhi has two PPP forms - a simple terminating in -yo (-io) employed to build perfective tenses (e.g. parhyo 'read') and a form extended by -alu (-yalu) which can be used attributively (rahayalu dīnhũ 'remaining day') and predicatively (33) as well (YeGOROVA 1971: 78-79) although the latter form does not seem to be fully incorporated in the verbal system of Sindhi. A participial form terminating in -ro was also attested by GRIERSON (1919: 55). Formally it is identical to the Rajasthani stative participle.

Another peculiarity of Sindhi is the formation of the so called actual tenses, i.e. tenses denoting an action in process actual for a given moment in the present, past or future. The tenses are built on the basis of a long converb in $-\bar{l}(-\bar{e})+$ PPP of the verb rahanu 'live, remain, stay' or huanu 'be'. It is noticeable that the actual tenses are formed according to the same patterns as in Eastern Pahari, however with an entirely disctinct meaning (cf (8) with (34)).

$$
\begin{array}{llll}
\text { nătak gharu sajo } & \text { bhar-yalu } & \text { ho } \\
\text { theatre.M.SG } & \text { entirely } & \text { fill-STAT.M.SG } & \text { be.AUX.PAST.M.3SG } \\
\text { 'The theatre was packed to capacity.' } &
\end{array}
$$

(YeGOROVA 1971: 79)

7 http://vedashri.blogspot.com/2006/01/blog-post_113803675993125528.html (This, and many other examples of the extended forms in -lel- with cliticized copula from Marathi have been provided to me by P.E. Hook). 


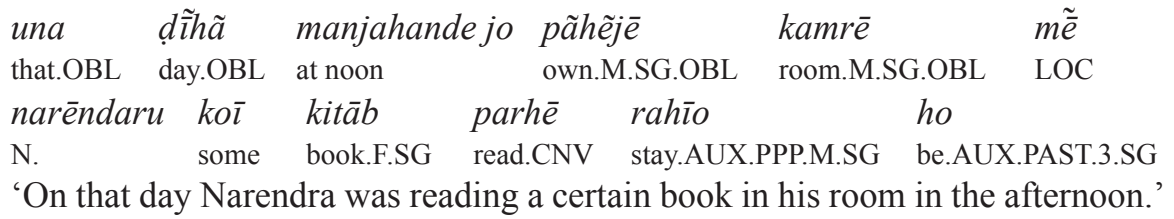

(Yegorova 1971: 100)

\section{CONVERBS AND PERFECTIVES}

It has already been observed in the Indo-Aryan scholarship that, for example, in Bengali, Oriya and literary Sinhala converbs (absolutives) with auxiliaries, instead of the PPP, are used to mark resultative (perfective). ${ }^{8}$ Western Pahari languages on the other hand are said to use the PPP forms extended by a variety of suffixes for the same purpose (MASICA 1991: 276). It seems that at least several dialects belonging to western branches (Koci Kuari, Jubbali and Mandeali) can employ so called short converbs formed by adding $-i(-e)$ to the root with auxiliaries er-, or- 'do, see' to express stative meanings, e.g. Koci Kuari khai ero 'having been eaten' or they use short converbs with a number of auxiliaries (among which there are etymological equivalents of the stative marker '-ero') to mark perfective aspect (ex. (35); cf. HENDRIKSEN 1986: 178, 186).

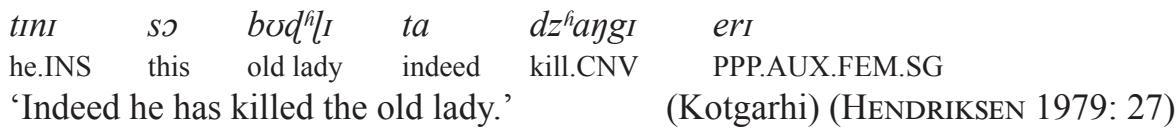

Some of the auxiliaries used in Western Pahari are either in the process of transition from an auxiliary towards suffix (e.g. Koci) or, as it is the case of Kului, they have already lost their verbal value and become suffixes.

Nepali, and to lesser extent Kumauni, employ the PPP with a suffix - $a$ or -eko respectively to mark perfectivity (MASICA 1991: 276). As we have seen above, Eastern Pahari uses a variety of auxiliaries combined with a short converb to mark perfective (also stative and resultative) meanings. Short converbs formed by a suffix $-i$ are also used widely in compound verbs and in serial verb constructions they are restricted to stylistic and idiomatic variations (ex. (36); cf. SHARma 1987: 125) and it is predominantly long forms terminating in -ber which are used independently (for a similar behaviour of the short and long converbs see Montaut 2004a: 93). Nepali converbs terminating in $-i$ or $-e$ are used in compound verbs but the latter one appears in serial verb construction as well, whereas forms in $-\bar{\imath}$ or those more recent in -era or -īkan are used independently (cf. KOROLEV 1965: 59-6; MASICA 1991: 323; WALLACE 1982: 167).

$$
\begin{aligned}
& \text { maĩ võ } \text { tak jai }(<j a+i) \quad \bar{a} y \tilde{\bar{u}} \\
& \text { I there to go.CNV come.PPP.1SG } \\
& \text { 'I have come back after having gone up to that point.' }
\end{aligned}
$$

(Kumauni) (SHARMA 1987: 125)

8 The perfective value of the IA converb has been widely discussed for example in DAVISON 1981; KACHRU 1981; Peterson 2002 etc. 


\section{EVOLUTION OF A MARKING - FROM RESULTATIVE TO PERFECTIVE}

The evolution from the stative/resultative to perfective can be traced on the basis of correlation between the form of the participle and the expression of $\mathrm{A}$.

Early Pahari shows the following developments in this respect. In eastern branch there are instances of the genitive A which appears in the earliest inscriptions from Nepal (37) but after the 16th century the genitive A was ousted by the ergative A (cf. Poudel 2008). However no such a development can be traced in the inscriptions from Kumauni (Stroński in press) where one cannot find any reliable attestations of the genitive A. Similarily in early Western Pahari inscriptions genitive A does not occur in the constructions based on the PPP, but on the other hand genitive $\mathrm{A}$ is present in another non-nominative pattern, namely in the obligative construction (38). In contemporary Eastern Pahari genitive A (or rather agent-like argument) is lexically restricted (see ex. (9); cf. KHOKHLOVA \& SingH 2007: 102).

$r \bar{a} i-k \bar{a} \quad b h \bar{a} s p_{0} \quad$ pas $\bar{a} \quad k i$-akri
king-GEN proclamation.F.SG gift do.PPP.F.SG-offer.PPP.F.SG
'The king has proclaimed a gift.'
Or 'The gift has been offered through a king's proclamation.'

(1321 AD) (PANT 2009: 323)

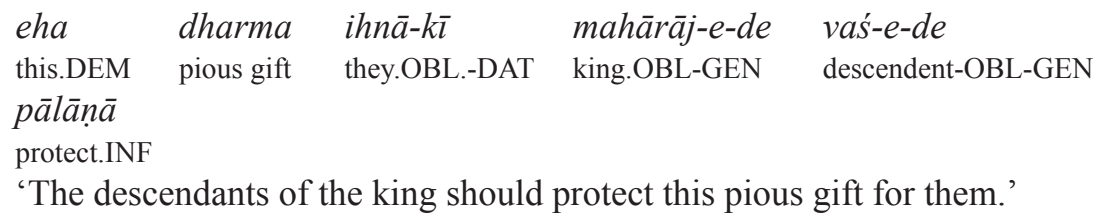

(1664 AD) (CHHABRA 1957: 160)

In Western Pahari languages, constructions based on the stative participles derived from transitive verbs have agents marked by genitive (39) or by ergative (ex. (12) and (13)). The genitive is more precisely a genitive in oblique case called 'relational case' by HENDRIKSEN (1986: 106-108) (for a variety of meanings of the genitive subjects in Western Pahari see ZOLLER 2008), and the construction based on a stative participle where relational case is employed resembles the one in Punjabi (40) (cf. Newton 1898: 297-298; KHokHLovA \& SiNGH 2007: 101-103). The syntax of the forms based on the PPP may differ from the syntax of the stative participle. In languages such as Kotgarhi constructions based on the stative participles employ exclusively relational case to mark A, whereas the PPP requires A marked by an instrumental/ergative. Thus, Kotgarhi, having such a clear cut distinction between constructions based on the PPP and the stative participle, stands in an opposition to Kului where the stative participle has become a member of the perfective paradigm. Kului has presumably undergone a shift during which the auxiliary 'to be' used in its finite form has been replaced by a participial form of 'to be' $(-u(n) d \bar{a}<h u n d a)$ or a suffix $-i-+$ a genitive marker $(-i r \bar{a}<-\bar{l}-+-r \bar{a})$ which in turn have become fully gramaticalized (cf. an example of a present perfect tense from Grierson (41) and a contemporary one (42)).

\begin{tabular}{|c|c|c|c|}
\hline $\begin{array}{l}\text { mere } \\
\text { I.GEN }\end{array}$ & $k^{h} a: \eta$ & 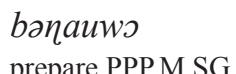 & $\begin{array}{l}n \supset \\
\text { AUX.M.SG }\end{array}$ \\
\hline
\end{tabular}




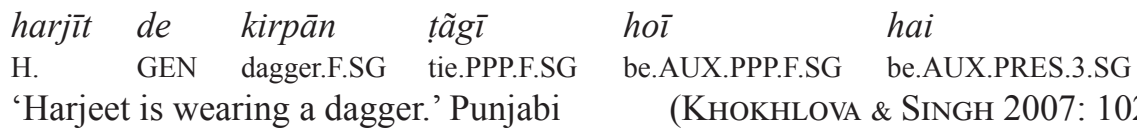

(KHOKHLOVA \& SINGH 2007: 102)

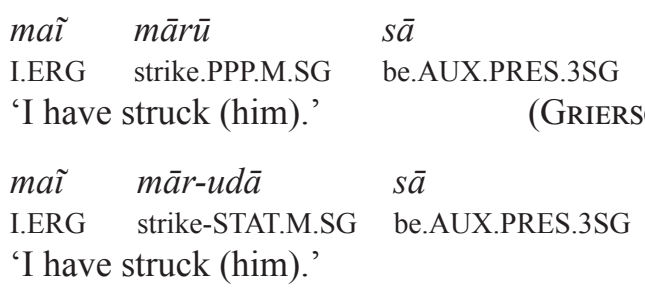

As we have seen in the first section, MSH under the influence of Punjabi introduced a resultative construction with overtly marked ergative A (ex. (4)). Although still considered to be substandard this construction was introduced at least a century ago (cf. PHILLOTT 1926).

\section{CONCLUSION}

The extension of the PPP is a very frequent phenomenon in the Indo-Aryan languages belonging to the north-western and western areas of the Indian subcontinent. It is, however, by no means a uniform phenomenon.

The PPP could be extended by the PPP form of the auxiliary to be (MSH, Punjabi), by the PPP form of the auxiliary 'stay', 'remain' (Old Marwari, Old Awadhi, MSH), by suffixes associated with genitive marking (Nepali, Kumaoni, Kului, Marwari, rarely Sindhi), by suffixes or auxiliaries derived from the present participle of the verb 'to be' (Old Marwari, Kului, Kotgarhi, Koci), by auxiliaries 'do', 'see' (Chameali, Mandeali, Koci Kuari, Jubbali or Bhadrawahi) or by the pleonastic suffixes -(i)l- (Gujarati) which can even be doubled (Marathi).

Some of the IA languages resort to combination of converbs + PPP of an auxiliary 'remain', 'put' etc. (Kumauni, Garhwali) instead of developing new PPP forms.

Such auxiliaries can be on their way to lose vector verb properties as it is the case of other IA languages (cf. MASICA 1991: 329). We have seen that this process began rather early - cf. the use of the verb rahna 'remain' in Old Marwari or Old Awadhi.

As we have seen in this paper, in several IA languages there is a tendency to include the extended form in the tense-aspect paradigm. The degree of inclusion of the extended forms differs, however, from language to language and there are various factors triggering the process. The PPP which is formally a verbal adjective has undergone a long path of grammaticalization - at the beginning of it we have a form fully endowed with stative/resultative properties and at end there is a form which has partly lost its stative force and as a part of verb paradigm it started serving as a finite form (with possible personal endings cliticisized, e.g. PPP in some Kumauni dialects).

The extended form fills the systemic gap - now it is the form to mark stative/resultative meanings and what is more it can become the part of the perfective paradigm (a model example of Kului). Formally, it can also evolve to finite form with personal endings cliticized (see Marathi example (32)). 
It has already been mentioned in the literature that there is a huge regional variation as regards A marking in the constructions based on the stative participles in modern western Indo-Aryan vernaculars such as Rajasthani, Gujarati and Punjabi. Rajasthani, being a language generally abandoning ergative pattern, employs exclusively nominative A whereas both Gujarati and Punjabi have ergative A (cf. KHokHLova \& SingH 2007: 97).

Pahari languages seem to show even more variety in this respect since, as we have seen, A can be marked by the ergative or the relative.

It seems thus that there is a general tendency as regards A marking in the constructions based on the stative participle. Languages which have abandoned the ergative pattern in the perfective domain (Rajasthani), naturally do not maintain it in the constructions based on the stative participles (cf. KHOKHLOva 1999: 109). Other languages have maintained it (eventually they could introduce another non-nominative pattern, e.g. constructions with the relative case - Western Pahari) or are in the process of reintroducing it under the areal pressure (e.g. Hindi).

\section{REFERENCES}

BAILEy Graham T. 1908. The Languages of the Northern Himalayas, Being Studies in the Grammar of Twenty-six Himalayan Dialects. London: The Royal Asiatic Society.

Bhaskararao Peri, Subbarao Karumuri Venkata (eds.). 2004. Non-nominal Subjects. Amsterdam: John Benjamins.

BhatT Purnanand Mahanand. 1889. A Handbook of Gujarati Grammar. Bombay.

Biș̣̣ Śersinh, Jośī Surendr. 2005. Janpadīy bhāṣā-sāhitya. Haldvānī: Ankit Prakāśan.

CARDOna George, JAIN Dhanesh (eds.). 2007. The Indo-Aryan Languages. London-New York: Routledge.

Cardona George, Suthar Babu. 2007. "Gujarati.” In: Cardona \& Jain 2007: 659-697.

DAšČENKo G.M. 1987. Rezul tativnye pričastja v jazyke urdu. Moscow: Moscow University publication.

Dave Trimbaklal. 1935. A Study of the Gujaräti Language in the $16^{\text {th }}$ Century (V.S.). London: School of Oriental Studies.

Deo Ashwini. 2006. Tense and Aspect in Indo-Aryan Languages: Variation and Diachrony. PhD thesis. Stanford University.

Doctor Raimond. 2004. A Grammar of Gujarati. München: Lincom Europa.

Grierson George A. [1903-1928]. Linguistic Survey of India. Calcutta: Superintendent Government Printing, India. Repr. 2005, Delhi: Low Price Publications.

GusAIN Lakhan. 2000. Bagri. München: Lincom Europa.

GusAIN Lakhan. 2001. Shekhavati. München: Lincom Europa.

GuSAIN Lakhan. 2003. Mewati. München: Lincom Europa.

GUSAIN Lakhan. 2004. Marwari. München: Lincom Europa.

Hendriksen Hans. 1986. Himachali Studies. III Grammar. Det Kongelige Danske Videnskabernes Selskab Historisk-filosofiske Meddelelser 48,3. København: Munksgaard.

Hock Hans Henrich. 1986. "P-oriented Construction in Sanskrit.” In: Krishnamurti et al. 1986: 15-26.

JaIn Dinesh, CARDONa George. 2007. The Indo-Aryan Langugaes. London: Routledge.

Joshi Maheshwar P., Negi Vidyadhar S. 1994. "Was there a Central Pahari? An Appraisal of Grierson's Classification of Three Pahari Languages Groups.” In: JosHi et al. 1994: 259-273.

Joshi Maheshwar P., Fanger Allen C., Brown Charles W. (eds.). 1994. Himalaya: Past and Present. Vol. III. Almora: Shree Almora Book Depot.

KaTENINA T.E. 1963. Očerk grammatiki jazyka maratxi. Moskva: Izdatel'stvo literatury na inostrannych jazykach.

Kellogg Samuel H. 1893. A Grammar of the Hindi Language. London: Kegan Paul, Trench, Trübner \& Co. Repr. 1972, New Delhi: Munshiram Manoharlal.

Kнокнцоva Ludmila V. 1999. "Stative Participles in Western NIA Languages.” In: Vidyopaasanaa: Studies in honour of Harivallabh C. Bhayani, 91-112. Mumbai: Image Publications. 
Khokhlova Ludmila V., Singh Charanjit. 2007. "Resultative Constructions in Western NIA Languages." In: MaSICA 2007: 91-108.

KhUBChandani Lachman M. 2007. “Sindhi.” In: CARDONA \& JAIN 2007: 622-658.

Krishnamurti Bhadriraju, Masica Collin P., Sinha Anjani K. (eds.). 1986. South Asian Languages. Structure, Covergence, Diglossia. Delhi: Motilal Banarsidass.

Korolev I.I. 1965. Jazyk nepali. Moskva: Izdatel'stvo 'Nauka'.

LienHARD Siegfried. 1961. Tempusgebrauch und Aktionsartenbildungen in der modernen Hindi. Stockholm-Göteborg-Uppsala: Almqvist \& Wiksell.

LIPEROVSKIJ Vladimir P. 1976. "Vyraženie značenija rezul'tativnogo sostojanija w xindi.” In: Indijskaja i iranskaja filologia, 100-114. Moskva: Izdatel'stvo 'Nauka'.

Masica Colin P. 1991. The Indo-Aryan Languages. Cambridge: Cambridge University Press.

Masica Colin P. (ed.). 2007. Old and New Perspectives on South Asian Languages Grammar and Semantics. Delhi: Motilal Banarsidass.

Mistry P.J. 1976. "Subject in Gujarati. An Examination of Verb-agreement Phenomenon.” In: VARMa 1976: 240-269.

Montaut Annie. 2004a. A Grammar of Hindi. München: Lincom Europa.

Montaut Annie. 2004b. "Oblique Main Arguments in Hindi/Urdu as Localizing Predications." In: BhasKarARAO \& SubBarao 2004: 33-56.

Nedjalkov Vladimir P. (ed.). 1988. Typology of Resultative Constructions. Amsterdam-Philadelphia: John Benjamins Publishing Company.

Nedjalkov Vladimir P., Jaxontov Siergiej E. 1988. "The Typology of Resultative Constructions." In: NedJALKOV 1988: 3-62.

Newton E.P. 1898. Punjabi Grammar with Excercises and Vocabulary. Ludhiana: Ludhiana Mission Press.

van Olphen Herman H. 1978. "Ergative and Causative in Hindi." Orbis 24, 184-204.

Pandharipande Rajeshwari. 2007. "Marathi." In: Jain \& CARdona 2007: 698-728.

Peterson John 1998. Grammatical Relations in Pali and the Emergence of Ergativity in Indo-Aryan. München: Lincom Europa.

Peterson John. 2002. “The Nepali Converbs: A Holistic Approach.” In: Singh 2002: 93-133.

Phillott Douglas Craven. 1926. "Note on the Statical and Some Other Participles in Hindustani." Bulletin of the School of Oriental Studies 4(1): 77-87.

Poudel Tikaram. 2008. Ergativity in Nepali: A Historical Perspective. Paper presented at the Workshop on Case and Alignment in Indo-European University of Bergen, 10-11 December 2008.

Ramsay H.N. 1842. The Principles of Gujarati Grammar. Bombay: Imperial Press.

SAKSEnA Baburam. 1937. Evolution of Awadhi. Allahabad: Indian Press. Repr. 1971, Delhi-Patna-Varanasi: Motilal Banarsidass.

ŚARMĀ Kanheyālāl. 1991. Pūrvī rājasthānī: udbhav aur vikās. Jaypur: The Students Book Company.

Saveleva L.V. 1965. Jazyk Gudžarati. Moskva: Izdatel'stvo 'Nauka'.

Sharma D.D. 1987. The Formation of Kumauni Language. Part II: Morphology and Syntax. New Delhi: Bahri Publications.

Sharma D.D. 1994. Linguistic Geography of Kumaun Hills. New Delhi: Mittal Publication.

STRoŃski Krzysztof. in press. "On the Syntax and Semantics of the Past Perfect Participle and Gerundive in Early NIA - Evidence from Eastern Pahari." Folia Linguistica Historica.

Singh Rajendra (ed.). 2002. Yearbook of South Asian Languages and Linguistics. New Delhi-Thousand OaksLondon: Sage Publications.

Tessitori Luigi Pio. 1914-1916. "Notes on the Grammar of the Old Western Rajasthani with Special Reference to Apabhramsa and Gujarati and Marwari." Indian Antiquary 43-45.

ȚHĀKUR Maulūrām. 1975. Pahāṛ̂̀ bhāṣā kuluī ke viśeș sa)darbh me). Dillī: Sanmārg Prakāśan.

Tisdall W. St. Clair. 1892. A Simplified Grammar of the Gujarati Language. London: Kegan Paul, Trench, Trübner \& Co. Ltd.

VARMa Manindra K. (ed.). 1976. The Notion of Subject in South Asian Langugaes. Madison: University of Wisconsin. South Asian Studies. Publication Series - Publication \#2.

Wallace William D. 1981. "Object-Marking in the History of Nepali: A Case of Syntactic Diffusion." Studies in the Linguistic Sciences 11(2): 107-128.

Wallace William D. 1982. "The Evolution of Ergative Syntax in Nepali." Studies in the Linguistic Sciences 12(2): 147-211. 
Yegorova Raisa P. 1971. The Sindhi Language. Moscow: 'Nauka' Publishing House.

Zoller Claus P. 2008. "Genitive Marking of Subjects in West Pahārị.” Acta Orientalia 69: 121-151.

\section{PRIMARY SOURCES}

BHĀNĀVAT Narendra, Kamal Lakshmi (eds.). 1997-1998. Rājasthān̄̄ gadya: vikās aur prakāś. Āgrā: Śīīām Mehrā end Kampanī. (R.G.)

CAUHĀn Candra Sim̄h. 2008. Kumāunī bhāṣā ke abhilekh. Haldvāni: Aṁkit Prakāśan.

Chrabra B.Ch. 1957. Antiquities of Chamba State. Part II. Memoires of the Archeological Survey of India, No 72. New Delhi: ASI.

Joshi Maheshwar P. 2009. "Advent of Polities in Uttarkhand (Kumaon and Garhwal).” In: Bards and Mediums: History, Culture, and Politics in the Central Himalayan Kingdoms, ed. by Marie Lecomte-Tilouin. Almora: Shri Almora Book Depot, 327-371. (Collection of Kumauni inscriptions).

PANT Mahes Raj. 2009. "Towards a History of the Khasa Empire.” In: Bards and Mediums: History, Culture, and Politics in the Central Himalayan Kingdoms, ed. by Marie Lecomte-Tilouin. Almora: Shri Almora Book Depot, 293-326. (Collection of early Nepali inscriptions).

PoKHAREL Bālkrș̣na. 1964. Pāñca śaya varșa. Lalitpur: Jagadambāprakāśan. (Collection of early Nepali inscriptions).

\section{WEB SITES}

http://ccat.sas.upenn.edu/plc/gujarati/pluperfect.htm.

http://vedashri.blogspot.com/2006/01/blog-post_113803675993125528.html. 